\title{
Ginkgo biloba extract (EGb 761) attenuates oxidative stress induction in erythrocytes of sickle cell disease patients
}

\author{
Aline Emmer Ferreira Furman*, Railson Henneberg, Priscila Bacarin Hermann, \\ Maria Suely Soares Leonart, Aguinaldo José do Nascimento
}

\author{
Post-Graduation Program in Pharmaceutical Sciences, Federal University of Paraná
}

\begin{abstract}
Sickle cell disease promotes hemolytic anemia and occlusion of small blood vessels due to the presence of high concentrations of hemoglobin S, resulting in increased production of reactive oxygen species and decreased antioxidant defense capacity. The aim of this study was to evaluate the protective action of a standardized extract of Ginkgo biloba (EGb 761), selected due to its high content of flavonoids and terpenoids, in erythrocytes of patients with sickle cell anemia (HbSS, SS erythrocytes) subjected to oxidative stress using tert-butylhydroperoxide or 2,2-azobis-(amidinepropane)-dihydrochloride, in vitro. Hemolysis indexes, reduced glutathione, methemoglobin concentrations, lipid peroxidation, and intracellular reactive oxygen species were determined. SS erythrocytes displayed increased rates of oxidation of hemoglobin and membrane lipid peroxidation compared to normal erythrocytes (HbAA, AA erythrocytes), and the concentration of EGb 761 necessary to achieve the same antioxidant effect in SS erythrocytes was at least two times higher than in normal ones, inhibiting the formation of intracellular reactive oxygen species $\left(\mathrm{IC}_{50}\right.$ of $\left.13.6 \mu \mathrm{g} / \mathrm{mL}\right)$, partially preventing lipid peroxidation $\left(\mathrm{IC}_{50}\right.$ of $\left.242.5 \mu \mathrm{g} / \mathrm{mL}\right)$ and preventing hemolysis $\left(\mathrm{IC}_{50}\right.$ of $10.5 \mu \mathrm{g} / \mathrm{mL}$ ). Thus, EGb 761 has a beneficial effect on the oxidative status of SS erythrocytes. Moreover, EGb 761 failed to prevent oxidation of hemoglobin and reduced glutathione at the concentrations examined.
\end{abstract}

Uniterms: Ginkgo biloba. Oxidative stress. Erythrocytes. Azo compounds. Sickle cell anemia.

A doença falciforme promove anemia hemolítica e oclusão dos pequenos vasos, causados pela presença de altas concentrações de hemoglobina S, cujas consequências incluem a produção aumentada de espécies reativas de oxigênio e diminuição da capacidade de defesa antioxidante. O objetivo desse estudo foi avaliar a ação protetora de um extrato padronizado de Ginkgo biloba (EGb 761), selecionado devido ao seu alto conteúdo de flavonóides e terpenóides, em eritrócitos de pacientes com anemia falciforme (HbSS, eritrócitos SS) submetidos ao estresse oxidativo usando terc-butil-hidroperóxido e 2,2-azobis(amidinopropano)-diidrocloreto, in vitro. Índices de hemólise, glutationa reduzida, concentração de metemoglobina, peroxidação lipídica e espécies reativas de oxigênio foram determinados. Eritrócitos de pacientes com anemia falciforme apresentaram taxas aumentadas de oxidação da hemoglobina e peroxidação lipídica e a concentração de EGb 761 necessária para atingir o mesmo efeito antioxidante foi pelo menos duas vezes maior em relação aos eritrócitos normais (HbAA, eritrócitos AA), inibindo a formação de espécies reativas de oxigênio $\left(\mathrm{IC}_{50}\right.$ de $\left.13.6 \mu \mathrm{g} / \mathrm{mL}\right)$, prevenindo parcialmente a peroxidação lipídica $\left(\mathrm{IC}_{50}\right.$ de $242.5 \mu \mathrm{g} / \mathrm{mL}$ ) e prevenindo a hemólise ( $\mathrm{IC}_{50}$ de $10.5 \mu \mathrm{g} / \mathrm{mL}$ ). Portanto, EGb 761 possui um efeito benéfico no estado oxidativo dos eritrócitos SS. Entretanto, o EGb 761 não preveniu a oxidação da hemoglobina e da glutationa reduzida, nas concentrações examinadas.

Unitermos: Ginkgo biloba. Estresse oxidativo. Eritrócitos. Compostos azo. Anemia falciforme.

*Correspondence: A. E. F. Furman.. Laboratório-Escola de Análises Clínicas, Universidade Federal do Paraná. Av. Lothário Meissner, 632 - Jardim Botânico, 80210-170 - Curitiba - PR, Brasil. E-mail: alinemmer@hotmail.com 


\section{INTRODUCTION}

In hemoglobinopathies, including sickle cell disease (SCD), red blood cells are rendered more susceptible to oxidative damage because they produce greater amounts of reactive oxygen species (Aslan, Thornley-Brown, Freeman, 2000). Moreover, in SCD red blood cells are more susceptible to oxidation (Chaves, Leonart, Nascimento, 2008) and have a reduced ability to defend against oxidation (Fasola et $a l ., 2007)$. The imbalance between pro- and antioxidant actions can lead to extensive oxidative damage of erythrocyte membrane components (Titus et al., 2004). SCD was the first monogenic human disease characterized at the molecular level. Erythrocyte defects observed in SCD resulted from the substitution of glutamic acid by valine at position 6 on the $\beta$ chain of hemoglobin thus forming hemoglobin $\mathrm{S}(\mathrm{Hb}$ $\mathrm{S})$ rather than normal hemoglobin A (Hb A) (Higgs, Wood, 2008). The SS genotype results in sickle cell anemia (SCA). Under conditions of low oxygen tension, $\mathrm{Hb} \mathrm{S}$ molecules polymerize, causing erythrocyte deformation and increased membrane rigidity. As a consequence, anemia and chronic hemolytic occlusion of small blood vessels occur, leading to tissue damage by ischemia (Titus et al., 2004).

Recognition of the role of reactive oxygen species (ROS) in the pathophysiology of SCA suggests a beneficial effect of supplements that increase the total antioxidant capacity in patients, and thus, reduce oxidative damage in erythrocytes.

Extracts of Ginkgo biloba are widely consumed as herbal remedies and dietary supplements and its leaves have been used in Chinese medicine for thousands of years. In recent years, standardized Ginkgo biloba leaf extracts with well-defined components have been developed, including EGb 761, which contains 24\% ginkgo-flavone glycosides and $6 \%$ terpenoids. Several studies have demonstrated the antioxidant action of EGb 761 in erythrocyte models of oxidative stress (He et al, 2008; Kose et al, 1997; Sarikcioglu, Oner, Tercan, 2004; Foroughinia, Karimi, 2007). However, to our knowledge, this is the first study examining the effect of EGb 761 in the prevention of oxidative damage in SCD.

Thus, it was important to analyze the antioxidant effect of EGb 761 in the erythrocytes of SCA patients in order to investigate whether this extract can protect them from oxidative injury in vitro, and to provide support for the use of EGb 761 as an antioxidant supplement in vivo, enabling further evaluation of it as a possible therapy for this patients.

\section{MATERIAL AND METHODS}

Tert-butylhydroperoxide ( $t$-BHP) and 2,2-azobis(amidinepropane) dihydrochloride (AAPH) were purchased from Across Organics and Sigma-Aldrich, respectively. EGb 761 was kindly donated from the Herbarium, and dissolved in 50\% propylene glycol in a stock solution of $20 \mathrm{mg} / \mathrm{mL}$ phosphate-buffered saline (PBS). All others reagents were of analytical grade.

Fresh blood was drawn from the antecubital vein of 20 healthy volunteers, students and professionals of Federal University of Paraná, considered as HbAA (AA erythrocytes) after normal blood count and hemoglobin solubility test; and 21 sickle cell disease patients, with previous diagnosis of HbSS (SS erythrocytes) condition by hemoglobin electrophoresis and solubility test, treated at Center of Hematology and Hemotherapy of Paraná (HEMEPAR) from October 2010 to February 2011, using EDTA $\mathrm{K}_{3}$ as an anticoagulant. Serum and buffy coats were removed by centrifugation at $1000 \times \mathrm{g}$ for $10 \mathrm{~min}$, and the red blood cell pellets were washed three times in cold isotonic PBS (10 mmol/L, pH 7.4). All erythrocytes suspensions were freshly prepared on a daily basis. The survey was approved by the Ethics Committee of the Federal University of Paraná (CEP/SD 778.113.09.08), and all subjects signed an informed consent form.

For each analysis (methemoglobin, TBARS, GSH, hemolysis and ROS production) it were used 5 patient/control samples, in triplicate. The analyses were done in basal states, after oxidant incubation (AAPH/t-BHP) and after EGb 761 + oxidant incubation (EGb 761 pre-incubation of $30 \mathrm{~min}$, according to He et al., 2008).

A stock solution of aqueous AAPH $(100 \mathrm{mmol} / \mathrm{L})$ was used in the hemolysis experiments. Suspensions of red blood cells ( $10 \%$ hematocrit) were incubated with EGb $761(0-250 \mu \mathrm{g} / \mathrm{mL})$ at $37^{\circ} \mathrm{C}$ for $30 \mathrm{~min}$, followed by AAPH at $37^{\circ} \mathrm{C}$ for $3 \mathrm{~h}$ under homogenization. Incubation was terminated by centrifugation at $1000 \times \mathrm{g}$ for $10 \mathrm{~min}$, and the absorbance of the supernatants was measured at 540 nm using a microplate reader (Thermoplate, Tecnoglobo, Brazil). The hemolysis of red blood cells in water was used as a control and was presumed to be $100 \%$.

The level of reduced glutathione level (GSH) in red blood cells ( $40 \%$ hematocrit) was determined in basal state and after treatment with EGb $761(0-250 \mu \mathrm{g} / \mathrm{mL})$ and $t$-BHP (10 mmol/L), using 5,5'-dithio-bis(2-nitrobenzoic) acid (DTNB) as a chromophore, as previously described by Beutler, 1984. Absorbance was measured at $412 \mathrm{~nm}$ using a spectrophotometer (Cintra 10 UV-VIS, GBC, Australia).

The concentration of methemoglobin present in erythrocytes in basal state and after treatment with EGb $761(0-250 \mu \mathrm{g} / \mathrm{mL})$ and $t$-BHP $(1 \mathrm{mmol} / \mathrm{L})$ was determined according to Naoum et al.(2004). Briefly, after treatment, an aliquot of the cell suspension (10\% hematocrit) was hemolysed with $1 \%$ saponine prior to the addition of 
phosphate buffer $60 \mathrm{mmol} / \mathrm{L}, \mathrm{pH}$ 6.8. Absorbance of the solution was adjusted with PBS and then read at $540 \mathrm{~nm}$ and $630 \mathrm{~nm}$ spectrophotometrically.

Erythrocyte lipid peroxides were measured as thiobarbituric acid reactive substances (TBARS) according to the protocol developed by Stocks and Dormandi, 1971, in basal state and after treatment. Erythrocytes $(10 \%$ hematocrit) were pre-incubated with EGb $761(0-250 \mu \mathrm{g} / \mathrm{mL})$ for $30 \mathrm{~min}$ at $37{ }^{\circ} \mathrm{C}$ and $t$-BHP $(2 \mathrm{mmol} / \mathrm{L})$ for $15 \mathrm{~min}$ at $37^{\circ} \mathrm{C}$. Absorbance was determined spectrometrically and malonyldialdehyde concentrations were calculated.

Erythrocytes suspensions (10\% hematocrit) were incubated in PBS at $37^{\circ} \mathrm{C}$ for $30 \mathrm{~min}$ in the presence of dichlorodihydrofluorescein-diacetate (DCF-DA) $10 \mu \mathrm{mol} / \mathrm{L}$. After incubation with the probe, the cell suspension was diluted 1:10 in PBS 10 mmol/L, pH 7.4 and incubated with increasing concentrations of EGb $761(0-250 \mu \mathrm{g} / \mathrm{mL})$ for 30 min at $37^{\circ} \mathrm{C}$. ROS production was determined by exposure to $t$ - $\mathrm{BHP}(75 \mu \mathrm{mol} / \mathrm{L}$ for $15 \mathrm{~min})$ at $37^{\circ} \mathrm{C}$ using a fluorimeter (Synergy HT, Biotek, USA), as described by López and Revuelta, 2005. Percentage of ROS formation was determined as DFC fluorescence/mg $\mathrm{Hb}$, and experimental samples were normalized to the fluorescence emitted by erythrocytes loaded with DCF-DA in the presence of the $t$-BHP.

Values were presented as means \pm standard deviation. Statistical significance of the experimental data was analyzed using t test, ANOVA and Dunnet tests. A p $<0.05$ value was considered to be significant. The Inhibitory Concentration $\left(\mathrm{IC}_{50}\right)$ necessary to inhibit $50 \%$ of the oxidation by $t$-BHP was defined in Prism 5 for Windows (GraphPad Software, Inc) using a sigmoidal dose-response model with variable slope, considering group $t$-BHP (without EGb 761) as $0 \%$ of inhibition. The best fit values for $\mathrm{IC}_{50}$ and its standard error were reported.

\section{RESULTS}

\section{Basal levels of methemoglobin, TBARS and GSH}

SS erythrocytes presented an increased endogenous oxidative stress in relation to AA erythrocytes, as seen in methemoglobin and TBARS basal content, while the basal content of GSH was the same in both groups (Table I).

\section{Pro-oxidant action of $t-B H P$ on glutathione, methemoglobin and TBARS levels}

Incubation of both AA and SS erythrocytes with the oxidant $t$-BHP led to the depletion of reduced GSH, formation of methemoglobin, and membrane lipoperoxidation. However, hemoglobin oxidation and lipid peroxidation were 1.2 and 1.9 times higher, respectively, in the SS group compared to the AA group (Table I).

\section{Antioxidant action of EGb 761 on glutathione, methemoglobin and TBARS levels}

In both AA and SS erythrocytes, the extract failed to prevent or reverse GSH and hemoglobin oxidation at the concentrations tested (Table I). Moreover, it partially prevented the peroxidation of membranes, both in erythrocytes of healthy subjects and patients with SCA, in a dose-dependent manner. In erythrocytes from SCA patients, pre-incubation with concentrations of $250 \mu \mathrm{g} / \mathrm{mL}$ EGb 761 inhibited lipid peroxidation by $50.6 \%$ (Table I).

TABLE I - Erythrocytes concentration of TBARS, glutathione and methemoglobin levels in normal subjects (AA) and sickle cell anemia patients (SS) incubated with Ginkgo biloba extract (EGb 761) in the presence of tert-butyl hydroperoxide ( $t$-BHP)*

\begin{tabular}{lcccccc}
\hline \multirow{2}{*}{ Treatment } & \multicolumn{2}{c}{ Glutathione $^{\S}$} & \multicolumn{2}{c}{ Methemoglobin $^{\S \S}$} & \multicolumn{2}{c}{ TBARS $^{\S \S}$} \\
\cline { 2 - 7 } & \multicolumn{2}{c}{$(\mu \mathrm{mol} / \mathrm{g} \mathrm{Hb})$} & \multicolumn{2}{c}{$(\%)$} & \multicolumn{2}{c}{$(\mathrm{nmol} / \mathrm{g} \mathrm{Hb})$} \\
\cline { 2 - 7 } & AA & SS & AA & SS & AA & SS \\
\hline Basal & $7.0 \pm 0.9$ & $7.2 \pm 0.8$ & $3.2 \pm 0.3$ & $5.0 \pm 0.4^{\mathrm{a}}$ & $21.2 \pm 6.7$ & $38.2 \pm 5.9^{\mathrm{a}}$ \\
-BHP & $0.7 \pm 0.3$ & $0.4 \pm 0.4$ & $10.0 \pm 1.6$ & $12.0 \pm 2.1$ & $235.1 \pm 37.1$ & $445.2 \pm 38.4$ \\
EGb 761 $(5 \mu \mathrm{g} / \mathrm{mL})+t$-BHP & $0.8 \pm 0.5$ & $0.4 \pm 0.4$ & $10.4 \pm 2.2$ & $11.9 \pm 2.5$ & $219.2 \pm 39.6$ & $466.9 \pm 40.6$ \\
EGb 761 $(10 \mu \mathrm{g} / \mathrm{mL})+t$-BHP & $1.0 \pm 0.7$ & - & $9.4 \pm 2.1$ & $12.0 \pm 2.1$ & $212.9 \pm 36.8$ & $451.5 \pm 34.4$ \\
EGb 761 $(125 \mu \mathrm{g} / \mathrm{mL})+t$-BHP & $1.2 \pm 0.8$ & - & $10.2 \pm 2.3$ & $13.1 \pm 2.3$ & $201.9 \pm 32.3$ & $438.4 \pm 54.9$ \\
EGb 761 $(50 \mu \mathrm{g} / \mathrm{mL})+t$-BHP & $0.6 \pm 0.3$ & $0.4 \pm 0.3$ & $10.2 \pm 2.4$ & $12.6 \pm 1.6$ & $179.5 \pm 32.7^{\mathrm{c}}$ & $427.8 \pm 76.5$ \\
EGb 761 $(125 \mu \mathrm{g} / \mathrm{mL})+t$-BHP & $0.7 \pm 0.7$ & - & $9.8 \pm 2.1$ & $11.8 \pm 2.2$ & $123.3 \pm 34.2^{\mathrm{b}}$ & $314.9 \pm 60.8^{\mathrm{b}}$ \\
EGb 761 $(250 \mu \mathrm{g} / \mathrm{mL})+t$-BHP & $0.9 \pm 0.8$ & $0.3 \pm 0.3$ & $10.2 \pm 2.6$ & $13.1 \pm 2.6$ & $82.9 \pm 26.7^{\mathrm{b}}$ & $224.1 \pm 40.1^{\mathrm{b}}$ \\
\hline
\end{tabular}

*Data represent the mean \pm standard deviation of 5 analyses in triplicate. Methemoglobin is expressed as a percentage of total hemoglobin. [-] Not determined. $t$-BHP concentration: ${ }^{\S} 10, \$ \S 1, \$ \S 2$ mmol/L. [Unpaired t test, P values: ${ }^{\text {a }}<0.001$ group SS Vs Group AA; ANOVA, P values: ${ }^{\mathrm{b}}<0.001,{ }^{\mathrm{c}}<0.05$ Vs Group $t$-BHP]. 


\section{Pro-oxidant action of AAPH on hemolysis}

The degree of hemolysis in response to AAPH treatment was determined to be reduced in erythrocytes from sickle cell patients compared to the control group. In the SS group, the hemolysis was $20 \%$, while in the AA group it was $40 \%$ (Figure 1).

\section{Antioxidant action of EGb 761 on hemolysis}

EGb 761 showed significant anti-hemolytic action, preventing hemolysis at low concentrations $(5 \mu \mathrm{g} / \mathrm{mL})$ in both AA and SS erythrocytes. This protection was dose dependent, reaching maximum inhibition at $25 \mu \mathrm{g} / \mathrm{mL}$ (Figure 1).

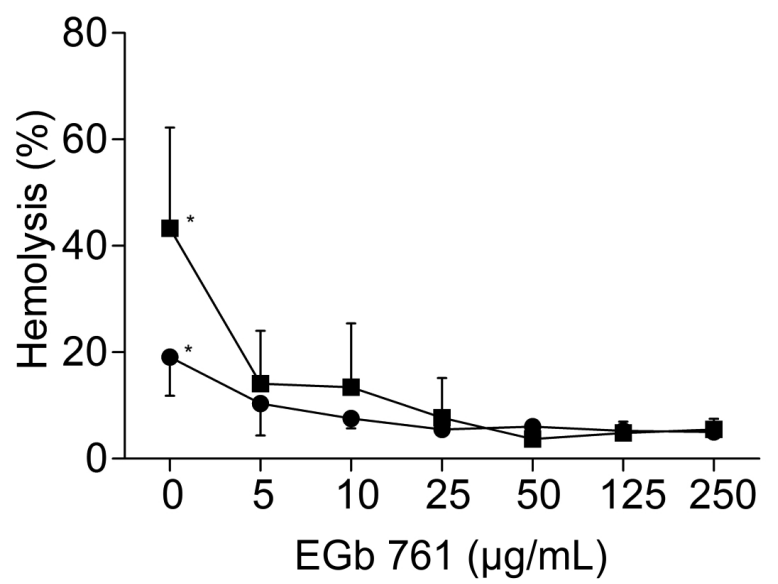

FIGURE 1 - Prevention of hemolysis in normal (घ) and sickle cell anemia (•) erythrocytes by EGb 761 exposed to AAPH $40 \mathrm{mmole} / \mathrm{L}$. Each experimental point represents the mean \pm standard deviation of 5 analyses in triplicate. [ANOVA, P values: ${ }^{\mathrm{a}}<0.001,{ }^{\mathrm{b}}<0.05$ Vs Group 0].

\section{Inhibitory Concentration 50\% (IC $\left.{ }_{50}\right)$ of EGb 761}

In in vitro assays, the concentration of EGB $761 \mathrm{ex}-$ tract required to inhibit $50 \%$ of lipid peroxidation induced by the oxidant $\left(\mathrm{IC}_{50}\right)$ was $141.0 \mu \mathrm{g} / \mathrm{mL}$ in erythrocytes of the AA group and $242.5 \mu \mathrm{g} / \mathrm{mL}$ in erythrocytes from the SS group (Table II).

The $\mathrm{IC}_{50}$ of the extract in the control group to prevent

TABLE II - Inhibitory Concentration 50\% $\left(\mathrm{IC}_{50}\right)$ of EGb 761 in isolated normal (AA) and sickle cell anemia (SS) human erythrocytes*

\begin{tabular}{lccc}
\hline Group & TBARS & ROS & Hemolysis \\
\hline AA & $141.0 \pm 1.1$ & $4.8 \pm 1.1$ & $4.5 \pm 1.3$ \\
SS & $242.5 \pm 1.1$ & $13.6 \pm 1.1$ & $10.5 \pm 1.6$ \\
\hline
\end{tabular}

* $\mathrm{IC}_{50}$ value was defined the as the effective concentration of EGb $761(\mu \mathrm{g} / \mathrm{mL})$ preventing $50 \%$ of $t$-BHP oxidation. Data represents mean \pm standard error of 5 analyses in triplicate. hemolysis was approximately two times lower $(4.5 \mu \mathrm{g} / \mathrm{mL})$ than the levels observed in erythrocytes from sickle cell patients $(10.5 \mu \mathrm{g} / \mathrm{mL})$ (Table II).

\section{Antioxidant action of EGb 761 on ROS production}

We found that all of the concentrations of EGb 761 tested inhibited ROS production when normal erythrocytes were exposed to $t$-BHP, and the level of protection reached $95.6 \%$ after incubation with EGb $761125 \mu \mathrm{g} / \mathrm{mL}$. In the erythrocytes of sickle cell patients, concentrations $\geq 10 \mu \mathrm{g} / \mathrm{mL}$ significantly inhibited ROS formation and the maximum inhibition reached was 93.2\% (Figure 2). Furthermore, EGb 761 showed greater activity in normal erythrocytes ( $\mathrm{IC}_{50}$ of $4.48 \mu \mathrm{g} / \mathrm{mL}$ ) compared to SS erythrocytes $\left(\mathrm{IC}_{50}\right.$ of $\left.13.6 \mu \mathrm{g} / \mathrm{mL}\right)$, which required more than twice the dose to achieve the same effect observed in the control group (Table II).

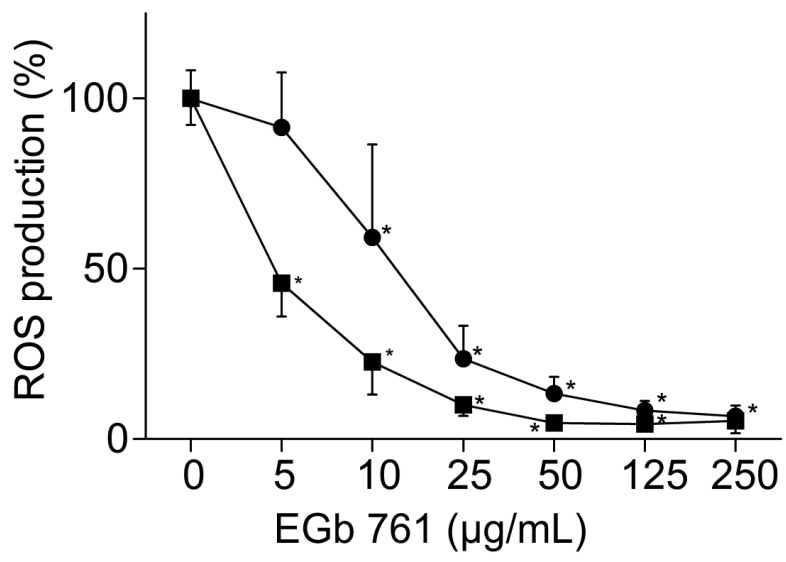

FIGURE 2 - Effect of EGb 761 on the inhibition of ROS production in normal ( $\bullet$ ) and sickle cell anemia $(\bullet)$ erythrocytes exposed to $t$-BHP $75 \mu$ mole/L. Each experimental point represents the mean \pm standard deviation of 5 analyses in quadruplicate. [ANOVA, P value: $*<0.001 \mathrm{Vs}$ Group 0].

\section{DISCUSSION}

Patients with SCD exhibit continuous depletion of antioxidant nutrients and depressed antioxidant enzyme activity in response to chronic oxidative stress. Impairment of the antioxidant system is associated with the increased severity of clinical manifestations. Therefore, antioxidant supplementation has been shown to improve erythrocyte survival and clinical outcome (Chan, Xia, Fu, 2007). It is widely accepted that these patients have increased concentrations of reactive oxygen species (Aslan, ThornleyBrown, Freeman, 2000; Morris et al., 2008). As expected, our experiments detected greater hemoglobin oxidation and lipid peroxidation in the erythrocytes of SS patients. 
A majority of studies on the SCD population have reported deficits in concentration of GSH (Hebbel et al., 1982; Wetterstroem, 1984; Hebbel, 1990; Hebbel, Leung, Mohandas, 1990; Aslan, Thornley-Brown, Freeman, 2000; Reid et al., 2006; Morris et al., 2008), while others have not found this pattern (Rice-Evans, Omorphos, Baysal, 1986; Somjee et al., 2004; Manfredini et al., 2008; Nur et al., 2011). Moreover, the GSSG (oxidized glutathione)/ GSH index was significantly elevated in SCD patients, supporting an important role for oxidative damage in these cells (Morris et al., 2008; Rusanova, 2010).

Chaves (2007) found decreased basal levels of GSH in erythrocytes of HEMEPAR SCA patients. Besides, in our experiments, as well as in Hermann (2011), the basal content of GSH was the same in both groups. This result suggests a protective effect of recent drug therapy, as hydroxyurea, and improvement in healthcare of SCA patients against spontaneous oxidation in vivo.

In fact, effective preventive measures including newborn screening, education of patients and caregivers, nutrition support, protective vaccinations and prophylaxis using penicillin to prevent pneumococcal, contribute to a decrease in the morbimortality as well as to improve quality of life of these patients (Braga, 2007).

In erythrocytes exposed to $t$-BHP, lipid peroxidation and hemoglobin degradation represent the extremes in a spectrum of oxidative damage. The reduction of $t$-BHP by GSH peroxidase (with GSH oxidation) effectively spares membrane lipids from peroxidation. Also, consumption of $t$-BHP by reaction with hemoglobin results in the generation of initiators of lipid peroxidation (Trotta, Sullivan, Stern, 1983). In this study, the action of $t$-BHP as a pro-oxidizer was more accentuated in SS compared to AA erythrocytes, presenting approximately $40 \%$ greater membrane lipo-peroxidation, higher hemoglobin oxidation, and near depletion of GSH levels.

When AAPH is added as an initiator, it decomposes at a physiological temperature $\left(37^{\circ} \mathrm{C}\right)$ in aqueous solutions to generate alkyl radicals $(\mathrm{R} \bullet)$, which in the presence of oxygen, are converted to the corresponding peroxyl radicals (ROO•). These peroxyl radicals induce the oxidation of polyunsaturated lipids (LH) in erythrocytes membranes, causing a chain reaction known as lipid peroxidation. As a result of lipid peroxidation, the membrane is quickly damaged and loses its integrity, leading to the release of hemoglobin (hemolysis) and intracellular $\mathrm{K}^{+}$ions (Banerjee et al., 2008). In this study, AAPH displayed strong hemolytic effects in erythrocytes. As Tatum and Chow (1996) showed, SS erythrocytes were more resistant to AAPH-induced hemolysis compared to normal erythrocytes.
Compounds such as EGb 761 can scavenge peroxyl radicals and convert them to non-reactive species, resulting in the inhibition of hemolysis, lipid peroxidation and hemoglobin oxidation.

In fact, two well-documented mechanisms of action of EGb 761 are the scavenging of free radicals and the chelation of transition metals (Rong, Geng, Lau, 1996; DroyLefaix, Packer, 1999; Lugasi, Horvahovich, Dworschak, 1999; Smith, Luo, 2004).

Kose and Dogan (1995) observed that the antioxidant potential of EGb 761 on hydrogen peroxide-induced lipoperoxidation in healthy human erythrocyte membranes increased in a dose- and time- dependent manner, in vitro. He et al. (2008), observed the same pattern with the $t$ BHP-induced formation of malonyldialdehyde in healthy human erythrocytes.

Furthermore, when the antioxidant effects of EGb 761 were compared with those of water-soluble and lipidsoluble antioxidants under the same in vitro system, EGb 761 was more effective than ascorbic acid, glutathione and uric acid, and as effective as $\alpha$-tocopherol and retinol acetate (Kose, Dogan, 1995). Moreover, EGb 761 displayed a concentration- dependent inhibitory effect on MDA production in the erythrocytes of both Behcet's patients (Kose et al., 1997) and G6-PD patients (Sarikcioglu, Oner, Tercan, 2004).

To our knowledge, it has not been reported that EGb 761 prevents oxidation in the erythrocytes of SCD patients. In our experiments, EGb 761 exhibited high antioxidant activity in both AA and SS erythrocytes, inhibiting $t$-BHP-induced reactive oxygen species (ROS) production and preventing $t$-BHP-induced membrane peroxidation and AAPH-induced hemolysis. However, the oxidative process induced by $t$-BHP in human erythrocytes starts from the fast oxidation of GSH, oxidation of the oxyhemoglobin, and then membrane lipid peroxidation. EGb 761 could not prevent the first two steps of oxidative damage, as demonstrated by its failure to prevent hemoglobin and GSH oxidation in erythrocytes. Nevertheless, the ability of EGb 761 to effectively scavenge ROS species was able to prevent damage to red cells membranes.

Increased endogenous oxidative stress in SS erythrocytes, as shown in Table I, was associated with severe damage induced by exogenous oxidants and is indicative of the need for increased antioxidant concentrations to reverse oxidative damage compared to control erythrocytes.

\section{CONCLUSION}

It was observed in the present work that in vitro antioxidant action of EGb 761 was dose-dependent, with $\mathrm{IC}_{50}$ 
at least two times greater in SCA erythrocytes than normal ones, preventing induced ROS production, membrane peroxidation and hemolysis. EGb 761 did not presented protective activity on GSH levels and hemoglobin oxidation. Clinical trials are needed to investigate the action of EGb 761 in increase survival of SCA erythrocytes in vivo.

\section{ACKNOWLEDGMENT}

The authors wish to thank Karina Konell, Rafaela Miravalhes, Michel Otuki, Cinthia Pelissari, and Gisele Mueller for their skillful help, and CAPES for financial support.

\section{REFERENCES}

ASLAN, M.; THORNLEY-BROWN, D.; FREEMAN, B.A. Reactive species in sickle cell disease. Ann. N. Y. Acad. Sci., v.899, p.375-391, 2000.

BANERJEE, A.; KUNWAR,A.; MISHRA, B.; PRIYADARSINI, $\mathrm{K}$. Concentration dependent antioxidant/pro-oxidant activity of curcumin: Studies from AAPH induced hemolysis of RBCs. Chem. Biol. Interact., v.174, p.134139,2008

BEUTLER, E. Red cell metabolism: a manual of biochemical methods. 3.ed. Orlando: Grune \& Stratton, 1984. 188 p.

BRAGA, J.A.P. Medidas gerais no tratamento das doenças falciformes. Rev. Bras. Hematol. Hemoter., v.29, p.233$238,2007$.

CHAN, P.; XIA, Q.; FU, P. Ginkgo Biloba leave extract: biological, medicinal, and toxicological effects. J. Environ. Sci. Health C. Environ. Carcinog. Ecotoxicol. Rev., v.25, p.211-244, 2007.

CHAVES, M.A.F. Ação antioxidante das vitaminas $C$ e E no processo oxidativo em eritrócitos de indivíduos portadores de hemoglobina S. Curitiba, 2007. 147 p. [Dissertation of Master degree in Pharmaceutical Sciences, Federal University of Paraná].

CHAVES, M.A.F.; LEONART, M.S.S.; NASCIMENTO, A.J. Oxidative process in erythrocytes of individuals with hemoglobin S. Hematology, v.13, p.187-192, 2008.
DROY-LEFAIX, M.T.; PACKER, L. Antioxidant properties of Ginkgo biloba extract: EGb 761. In: PACKER, L.; HIRAMATSU, M.; YOSHIKAWA, T. (Eds.). Antioxidant food supplements in human health. San Diego: Academic Press, 1999. p.344-353.

FASOLA, F.; ADEDAPO, K.; ANETOR, J.; KUTI, M. Total antioxidants status and some hematological values in sickle cell disease patients in steady state. J. Natl. Med. Assoc., v.99, p.891-893, 2007.

FOROUGHINIA, F.; KARIMI, M. The protective effects of Ginkgo biloba extract in decreasing hemolysis of RBC in Glucose-6-phosphate dehidrogenase-deficient patients. $J$. Pediatr. Hematol. Oncol., v.29, p.511-512, 2007.

HE, J.; LIN, J.; LI, J.; ZHANG, J.H.; SUN, X.M.; ZENG, C.M. Dual effects of Ginkgo biloba leaf extract on human red blood cells. Basic Clin. Pharmacol. Toxicol., v.104, p.138144, 2008.

HEBBEL, R.P.; EATON, J.W; BALASINGAM, M; STEINBERG, M.H. Spontaneous oxygen radical generation by sickle erythrocytes. J. Clin. Invest., v.70, p.1253-1259, 1982.

HEBBEL, R.P. The sickle erythrocyte in double jeopardy: autoxidation and iron decompartmentalization. Semin. Hematol., v.27, p.51-69, 1990

HEBBEL, R.P.; LEUNG, A.; MOHANDAS, N. Oxidationinduced changes in microrheologic properties of the red blood cell membrane. Blood, v.76, p.1015-1020, 1990.

HERMANN, P.B. Ação de desferoxamina e deferasirox em eritrócitos de portadores de anemias dependentes de transfusão, com sobrecarga oxidativa, in vitro, 2011.131 p. [Dissertation of Master degree in Pharmaceutical Sciences, Federal University of Paraná].

HIGGS, D.R.; WOOD, W.G. Genetic complexity in sickle cell disease. Proc. Natl. Acad. Sci. USA, v.105, p.11595-11596, 2008 .

KOSE, K.; DOGAN, P.; ASCIOGLU, M.; ASCIOGLU, O. In vitro antioxidant effect of Ginkgo biloba extract (EGb 761) on lipoperoxidation induced by hydrogen peroxide in erythrocytes of Behcet's patients. Jpn. J. Pharmacol., v.75, p.253-258, 1997. 
KOSE, K.; DOGAN, P. Lipoperoxidation induced by hydrogen peroxide in human erythrocyte membranes. J. Int. Med. Res., v.23, p.1-18, 1995.

LÓPES-REVUELTA, A.; SÁNCHEZ-GALLEGO, J.; HERNÁNDEZ-HERNÁNDEZ, A.; SÁNCHEZ-YAGGE, J.; LLANILO, M. Increase in vulnerability to oxidative damage in cholesterol-modified erythrocytes exposed to t-BuOOH. Biochim. Biophys. Acta, v.1734, p.74-85, 2006.

LUGASI, A.; HORVAHOVICH, P.; DWORSCHAK, E. Aditional information to the in vitro antioxidant activity of Ginkgo biloba L. Phytother. Res., v.13, p.160-162, 1999.

MANFREDINI, V.; LAUERMANN, L.; GRIEBELER, I.H.; SANTINI, A.P.; BRANDÃO, V.D.M.; WAGNER, S.; CASTRO, S.M. Blood antioxidant parameters in sickle cell anemia patients in steady state. J. Natl. Med. Assoc., v.100, p.897-902, 2008.

MORRIS, C.; SUH, J.H.; HAGAR, W.; LARKIN, S.; BLAND, D.A.; STEINBERG, M.H.; VICHINSKY, E.P.; SHIGENAGA, M.; AMES, B.; KUYPERS, F.A.; KLINGS, E.S. Erythrocyte glutamine depletion, altered redox environment, and pulmonary hypertension in sickle cell disease. Blood, v.111, p.403-410, 2008.

NAOUM, P.C.; RADISPIEL, J.; MORAES, M.S. Dosagem espectrométrica de metaemoglobina sem interferentes químicos ou enzimáticos. Rev. Bras. Hematol. Hemoter., v.26, p.19-22, 2004.

REID, M.; BADALOO, A.; FORRESTER, T.; JAHOOR, F. In vivo rates of erythrocyte glutathione synthesis in adults with sickle cell disease. Am. J. Physiol. Endocrinol. Metab., v.291, p.73-79, 2006.

RICE-EVANS, C.; OMORPHOS, S.C.; BAYSAL, E. Sickle cell membranes and oxidative damage. Biochem. J., v.327, p.265-269, 1986.

RONG, Y.; GENG, Z.; LAU, B. Ginkgo biloba modulates glutathione redox cycle in vascular endothelial cells. Nutr. Res., v.16, p.1913-1923, 1996.
RUSANOVA, I.; ESCAMES, G.; COSSIO, G.; BORACE, R.G.; MORENO, B.; CHAHBOUNE, M.; LOPEZ, L.C.; DIEZ, T.; ACUÑA-CASTROVIEJO, D. Oxidative stress status, clinical outcome, and b-globin gene cluster haplotypes in pediatric patients with sickle cell disease. Eur. J. Haematol., v.85, p.529-537, 2010.

SARIKCIOGLU, S.; ONER, G.; TERCAN, E. Antioxidant effect of EGb 761 on hydrogen peroxide-induced lipoperoxidation of G-6-PD deficient erythrocytes. Phytother. Res., v.18, p.837-840, 2004.

SMITH, J.V.; LUO, Y. Studies on molecular mechanisms of Ginkgo biloba extract. Appl. Microbiol. Biotechnol., v.61, p.465-472, 2004.

SOMJEE, S.; WARRIER, R.P.; THOMSON, J.L.; ORYASCANI, J.; HEMPE, J.M. Advanced glycation endproducts in sickle cell anaemia. Br. J. Haematol., v.128, p.112-118, 2004.

STOCKS, J.; DORMANDY, T.L. The autoxidation of human red cell lipids induced by hydrogen peroxide. Br. J. Haematol., v.20, p.95-111, 1971.

TATUM, V.L.; CHOW, C.K. Antioxidant status and susceptibility of sickle erythrocytes to oxidative and osmotic stress. Free Radic. Res., v.25, p.133-139, 1996.

TITUS, J.; CHARI, S.; GUPTA, M.; PAREKH, N. Pro-oxidant and antioxidant status in patients of sickle cell anemia. Indian J. Clin. Biochem., v.19, p.168-172, 2004.

TROTTA, R.; SULLIVAN, S.G.; STERN, A. Lipid peroxidation and haemoglobin degradation in red blood cells exposed to t-butyl hydroperoxide. Biochem. J., v.212, p.759-772, 1983.

WETTERSTROEM, N.; BREWER, G.J.; WARTH, J.A.; MITCHINSON, A.; NEAR, K. Relationship of glutathione levels and Heinz body formation to irreversibly sickled cells in sickle cell. J. Lab. Clin. Med., v.103, p.589-596, 1984.

Received for publication on $09^{\text {th }}$ March 2012 Accepted for publication on $20^{\text {th }}$ July 2012 